\title{
Theoretical evaluation of iodine and selenium speciation in the natural waters of iodine- deficient territories
}

\author{
Liudmila Kolmykova ${ }^{1, *}$, Elena Korobova ${ }^{1}$, Boris Ryzhenko ${ }^{1}$, and Elena Cherkasova $^{1}$ \\ ${ }^{1}$ RAS, Vernadsky Institute of Geochemistry and Analytical Chemistry, 19 Kosygina St., 119234 \\ Moscow, Russia
}

\begin{abstract}
Water migration of iodine, selenium are in many cases directly related to manifestation of thyroid pathologies, in particular, the endemic goiter. The main aim was to evaluate species and conditions of migration of these elements in natural waters from different water-bearing rocks in areas with a natural iodine deficiency. Evaluation of iodine and selenium species in aqueous solutions has been carried out by thermodynamic modeling basing on chemical composition of 81 water samples taken in the Bryansk region in the period of 2015-2017. The study has showed that the predominant species of iodine in the natural waters is iodide-ion $(89 \%)$, which may also associate with typomorphic ions $(\mathrm{Ca}, \mathrm{Mg}, \mathrm{Na}, \mathrm{K}, \mathrm{Sr})$ forming mineral complexes with them. In the latter state iodine may be removed from solution by fixation on a carbonate barrier. Selenium dominates in natural waters as hydroselenide ion $(91 \%)$. In the presence of a significant amount of iron, this trace element may form the FeSe mineral phase which may be fixed in reduction conditions.
\end{abstract}

\section{Introduction}

Iodine is an essential element for development and functioning of all mammals and humans in particular [1, 2]. Prolonged iodine deficiency leads to disruption of adaptation mechanisms and the occurrence of iodine-deficient diseases [3]. Nowadays there is a large amount of data on the role of selenium in functioning of thyroid gland, i.e. secretion of its hormones [4, 5] and manifestations of Iodine Deficiency Disorders (IDD) [6, 7].

Despite the fact that with drinking water no more than $25 \%$ of the daily requirement for chemicals is satisfied, water components have a higher physiological value as compared to solid products [8]. A number of studies have shown that chemical composition of water can play an important role in the development of IDD (mainly goiter) [9, 10].

The Bryansk region, which is endemic for the goiter, was the most affected by radioactive contamination (including iodine radioisotopes) as a result of the accident at the Chernobyl nuclear power plant in 1986. The accident at the Chernobyl Nuclear Power Plant led to a 2.7-fold increase in the incidence of thyroid pathology in this area [11].

${ }^{*}$ Corresponding author: kmila9999@gmail.com 
Iodine and selenium in natural waters can exist in the form of simple ions and molecules as well as complexes with organic matter [12]. In addition, these chemical elements are able to associate with different sizes particles existing in natural waters, including colloidal and suspended fractions, separated by filtration [13]. The water formed in geochemically different conditions in accordance with the composition of the water-bearing rocks may vary significantly in concentration and forms of the trace elements under consideration which therefore make different contributions to the iodine and selenium dietary intake.

The purpose of this work was to peculiarities of water migration of iodine and selenium, in particular the speciation, in natural waters of different water-bearing sedimentary rocks to assess the contribution of mobile forms to the supply of these trace elements with drinking water.

\section{Study area, sampling technique and methodology of evaluating iodine and selenium speciation}

\subsection{Study area and sampling}

The drinking water supply of the Bryansk region is provided mainly through the exploitation of underground water sources [14]. The Bryansk region is located in the junction zone of two large artesian basins: the Moscow one (on the south-western side of the region) and the Dneprovsky (on the north-eastern side). The Callovian clay horizon, that is widespread in most part of the territory, causes isolation of the pre-Callovian aquatic system, which combines Cretaceous and Quaternary aquifers by its separation from the under-Callovian aquifers of the Devonian and upper Cambrian formations.

The two large hydrogeological structures form two different hydrogeological areas. The area of the Moscow artesian basin is characterized by the spread of upper Devonian aquifers, covered by the upper Jurassic regional confining layer. The artesian waters of the Devonian horizon are used as the main source of centralized drinking water supply in the northeast part of the region. Another hydrogeological area belongs to the Dnieper artesian basin and covers the south-western part of the region. The centralized water supply of these areas is based mainly on the aquifers of the lower and upper parts of the Cretaceous system (Turon-Maastricht terrigenous-carbonate and Alb-Senomanian terrigenous complex). For decentralized individual water supply, groundwater of the Quaternary sediments, opened by wells, is widely used.

Water sampling was carried out in the summer period of 2015-2017 from different sources confined to water-bearing rocks of various ages, which were used for drinking water supply of rural settlements as well as from rivers and lakes. Sampling was carried out according to standard methods.

\subsection{Thermodynamic modelling. Characteristics of the used thermodynamic model}

Assessment of the iodine and selenium speciation in natural waters of the Bryansk region was performed thermodynamic modeling $[15,16]$ using original experimental data obtained for 81 water samples.

The water-rock system was simulated using the following conditions: $\mathrm{T}=20^{\circ} \mathrm{C}$ (surface water) and $10^{\circ} \mathrm{C}$ (groundwater), total pressure Ptotal $=1 \mathrm{~atm}$. Free energy values for the ions and their complexes was taken from the UNITHERM database (Department of Geochemistry, Moscow State University). Bulk composition of the system was calculated basing on data on chemical analysis of the water samples. The created equilibrium 
multicomponent heterogeneous water-rock system was thermodynamically open for oxygen and carbon dioxide and included an aqueous solution, individual solid phases and sorbent phases: iron hydroxide $\left(\mathrm{FeO}(\mathrm{OH})\right.$ and manganese dioxide $\left.\left(\mathrm{MnO}_{2}\right)\right)$. The hydrochemical model consisted of 20 independent elements ( $\mathrm{H}, \mathrm{O}, \mathrm{C}, \mathrm{N}, \mathrm{Ca}, \mathrm{Sr}, \mathrm{Mg}, \mathrm{K}, \mathrm{Na}, \mathrm{Zn}, \mathrm{Fe}, \mathrm{F}, \mathrm{Cl}$, $\mathrm{S}, \mathrm{P}, \mathrm{I}, \mathrm{Se}, \mathrm{Si}, \mathrm{Al}, \mathrm{Mn})$ and 139 dependent components (122 chemical components of solution and 17 solid mineral phases, including sorbents, considered as ideal solid solutions). The model aqueous solution contained 14 species of iodine $\left(\mathrm{I}^{-}, \mathrm{I}^{3-}, \mathrm{CaI}^{+}, \mathrm{CaI}_{2}\right.$, $\left.\mathrm{HI}, \mathrm{IO}^{-}, \mathrm{IO}_{3}^{-}, \mathrm{HIO}_{3}, \mathrm{KI}, \mathrm{MgI}^{+}, \mathrm{MgI}_{2}, \mathrm{NaI}, \mathrm{SrI}^{+}, \mathrm{SrI}_{2}\right)$ and 7 of selenium $\left(\mathrm{HSe}^{-}, \mathrm{H}_{2} \mathrm{Se}, \mathrm{SeO}_{3}{ }^{2-}\right.$, $\mathrm{HSeO}^{3-}, \mathrm{H}_{2} \mathrm{SeO}_{3}, \mathrm{SeO}_{4}{ }^{2-}, \mathrm{HSeO}_{4}^{-}$).

Statistical processing of the obtained chemical analysis data was performed using standard functions of MS Excel 2010 and STATISTICA 10.0.

\section{Results}

\section{1 lodine}

Thermodynamic modeling showed that the predominant species of iodine migration in natural waters of Bryansk region is iodide-ion, which percentage can reach $89 \%$ (Fig. 1). According to the data obtained in the course of calculations on a new experimental material, the assumption was confirmed that the high mobility of iodine in the studied natural waters can be caused by migration not only in the form of simple ions ( $\left.\mathrm{I}^{-}, \mathrm{IO}_{3}^{-}\right)$, but also complex compounds, both organic and minerals in the form of $\mathrm{CaI}^{+}, \mathrm{MgI}^{+}, \mathrm{KI}, \mathrm{NaI}$. In early works it has already been shown $[17,18]$. The content of complex iodine ions with calcium, potassium, magnesium, sodium and stable strontium in the studied waters was $2.2 \%, 1.25 \%, 0.9 \%, 3.4 \%$ and $1.3 \%$, respectively. The rest of the considered species of iodine accounted for no more than $0.45 \%$.

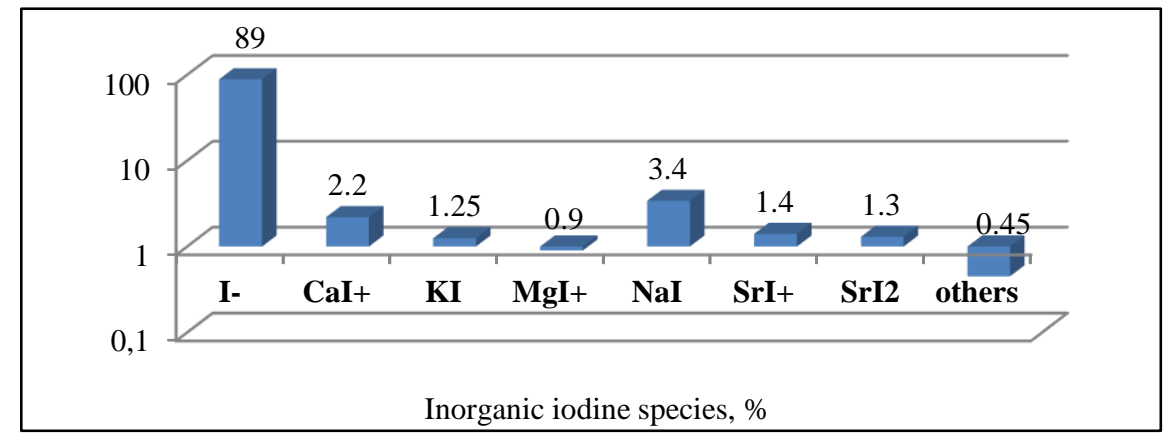

Fig. 1. The mean percentage of calculated inorganic species of iodine in the samples of natural waters.

The ratios of iodine species in natural waters depended on the type of water-bearing sediments and varied correspondingly in proportion to the total iodide content. Nevertheless, the iodide ion considerably dominated in all cases, changing within a very narrow range (from 91.3 to $94 \%$, Table 1). 
Table 1. The percentage of calculated inorganic species of iodine in natural waters originating from sediments of various type.

\begin{tabular}{|c|c|c|c|c|c|c|c|c|c|}
\hline $\begin{array}{c}\text { Sediment } \\
\text { type }\end{array}$ & $\begin{array}{c}\text { Type of } \\
\text { water source }\end{array}$ & I- & CaI+ & KI & MgI+ & NaI & SrI+ & SrI2 & oth. \\
\hline Quaternary & $\begin{array}{c}\text { Rivers, lakes, } \\
\text { wells }\end{array}$ & 91.3 & 1.9 & 1.7 & 2 & 1.2 & 0.9 & 0.4 & 0.6 \\
\hline Paleogene & $\begin{array}{c}\text { Wells, drilled } \\
\text { wells }\end{array}$ & 92.6 & 2.4 & 1.6 & 1.9 & 0.9 & 0.09 & 0.09 & 0.5 \\
\hline Cretaceous & $\begin{array}{c}\text { Wells, drilled } \\
\text { wells, tap } \\
\text { waters }\end{array}$ & 94 & 2.3 & 1.2 & 2.1 & 0.2 & 0.05 & 0.06 & 0.4 \\
\hline
\end{tabular}

The modeling has also showed that most of the considered waters are are in a steady state with carbonate minerals, quartz, apatite and some others, which corresponds to the mineral composition of the water-bearing rocks [19] (Table 2). The dominant solid phase of the waters draining the Quaternary sediments is quartz (up to $70 \%$ of the total). The largest proportion of calcite and dolomite (49.7 and 23.8\%), as expected, was observed in the waters of Cretaceous deposits.

Table 2. Dominating solid phases $(\mathrm{mol} / \mathrm{kg})$ in water samples from different sediments $\left(\operatorname{lgP~} \mathrm{O}_{2}\right.$ for all samples $=-63$ bar) $($ modern Quaternary deposits- $\boldsymbol{Q}$, Cretaceous deposits- $\boldsymbol{K}$, Paleogene deposits- $\boldsymbol{P})$.

\begin{tabular}{|c|c|c|c|c|c|c|c|c|c|c|}
\hline \multirow[t]{2}{*}{ Sediment type } & \multicolumn{10}{|c|}{ Solid phases } \\
\hline & $\begin{array}{l}\text { 苛 } \\
\text { 荌 }\end{array}$ & 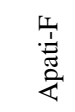 & 愛 & Ũ. & $\begin{array}{l}\stackrel{0}{*} \\
\frac{0}{0} \\
\end{array}$ & 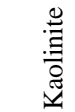 & 莺 & 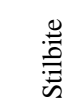 & 竎. & $\frac{\stackrel{0}{0}}{\frac{0}{0}}$ \\
\hline$Q$ & 0.02 & 0.68 & 24.8 & - & - & 0.02 & 70.2 & 0.36 & - & 2.58 \\
\hline$p$ & 0.02 & 0.49 & 4.56 & 31.1 & - & 0.003 & 63.8 & 0.003 & - & - \\
\hline$K$ & 1.33 & 0.05 & - & 49.7 & 23.8 & 0.05 & 24.4 & 0.05 & 0.58 & 0.01 \\
\hline
\end{tabular}

\subsection{Selenium}

According to our estimation, selenium in the studied waters is present mainly in the species of hydroselenide anion ( $\mathrm{HSe}^{-}$), the product of the first dissociation stage of seleniumcontaining acids. The average content of this species of the trace element for all waters reached $91 \%$ (Fig. 2).

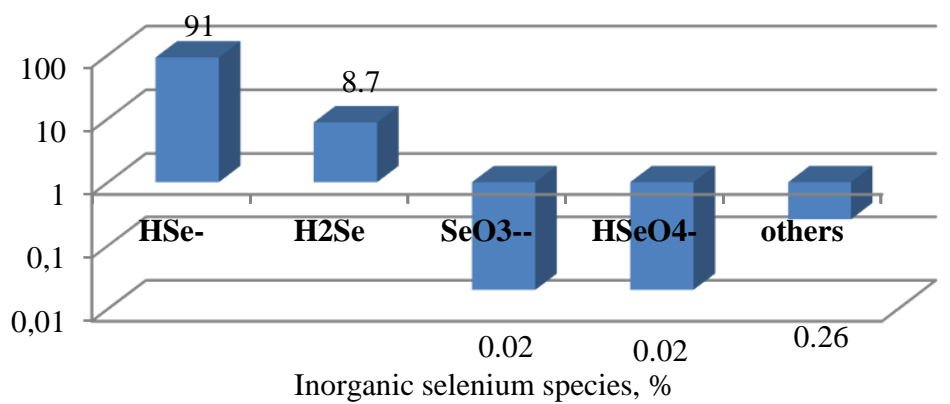


Fig. 2. The mean percentage of calculated inorganic species of iodine in the samples of natural waters.

\section{Conclusions}

Thermodynamic modeling showed that water migration of $\mathrm{I}$ in surface and underground waters occurs mainly in the species of iodide ion, the share of which reaches $94 \%$ of the inorganic species in total. Formation of water-soluble complexes of $\mathrm{CaI}^{+}$(up to $2.4 \%$ of the total) and $\mathrm{MgI}^{+}$(up to $2.1 \%$ of the total) can contribute to retention of the element in aqueous phase with a high content of relevant macroelements. On the other hand, as mentioned earlier, the complexes with $\mathrm{Ca}^{+}$and $\mathrm{Mg}^{+}$may be fixed on the carbonate barrier. Dominating species of selenium in the studied natural waters is hydroselenide (comprising up to $91 \%$ of the total inorganic Se pool). A significant role in iodine and selenium speciation in water is played by iron. In case of its increased amount in solution, goethite is formed, which sorbs iodine and forms iron selenide. In the latter case the mentioned processes can lead to elimination of the trace elements from the aqueous phase by their transfer to the mineral one, thus impoverishing waters in both I and Se.

\section{References}

1. V.V. Kovalsky, Biological role of iodine. Scientific works of the Academy of Agricultural Sciences, 3-32 (1972)

2. N.M. Platonova, Clin. and experim.1 thyroid., 11, 12-21 (2015)

3. G.A. Gerasimov, V.V. Fadeev, N.Yu. Svirenko, G.A. Melnichenko, I.I. Dedov, Iodine deficiency disorders in Russia. A simple solution to a complex problem, 168 (2002)

4. V.V. Ermakov, Electr. sci. inform. j., 22, 1-17 (2004)

5. O.A. Gromova, I.Yu. Torshin, N.G. Kosheleva, Breast Cancer: Mother and Child. Obstetrics and gynecology, 3, 80-87 (2011)

6. F.M. Fordyce, C.C. Johnson, U.R.B. Navaratna, J.D. Appleton, S.B. Dissanayake, The Sci. of the Total Environ., 263, 127-141 (2000)

7. V.V. Shakhtarin, A.F. Tsyb, V.F. Stepanenko et al., Int J. Epidemiol, 32, 584-591 (2003)

8. V.G. Kondratyev, General hygiene, 284 (1970)

9. N.M. Platonova, Iodine deficiency diseases (prevention, diagnosis, treatment and monitoring), 46 (2010)

10. Sh.K. Salikhov, M.A. Yakhiyaev, S.G. Luganova, M.G. Ataev, Z.V. Kurbanova, K.A. Alimetova, Bull.Tomsk Un., 19, 1729-1732 (2014)

11. V.P. Troshin, Characteristics of thyroid cancers in the region affected by the accident at the Chernobyl nuclear power plant (1986-2006), 39 (2009)

12. D.I. Kaplan, S. Zhang, K.A. Roberts, K. Schwehr, C. Xu, D. Creeley et al., J. Env. Radioact., 131, 57-61 (2014)

13. T.M. Florence, G.E. Batley, CRC Critical Rev. Anal. Chem, 9, 219-296 (1980)

14. State report, Committee for Nature Management and Environmental Protection, licensing certain types of activities in the Bryansk region, 285 (2012)

15. D.V. Grichuk, Thermodynamic models of submarine hydrothermal system, 304 (2000)

16. B.N. Ryzhenko, Geology of ore deposits, 50, 179-216 (2008) 
17. E.M. Korobova, B.N. Ryzhenko, E.V. Cherkasova, E.M. Sedykh, N.In. Korsakova, V.N. Danilova, S. D. Khushvakhtova, V.Yu. Berezkin, Geochem., 554-568 (2014)

18. E. Korobova, L. Kolmykova, B. Ryzhenko, E. Makarova, V. Shkinev, E. Cherkasova, N. Korsakova, I. Gromyak, V. Berezkin, V. Baranchukov, J. Geochem. Explor, 184, 311-317 (2018)

19. L.I. Kolmykova, E.M. Korobova, B.N. Ryzhenko, Bull. Tyumen St. Un., 2, 8-19 (2016) 